\title{
Spatial heterogeneity in the food web of a heavily modified Mediterranean coastal lagoon: stable isotope evidence
}

\author{
Antoine Carlier ${ }^{1,3, *}$, Pascal Riera ${ }^{2}$, Jean-Michel Amouroux ${ }^{1}$, Jean-Yves Bodiou ${ }^{1}$, \\ Martin Desmalades ${ }^{1}$, Antoine Grémare ${ }^{1,4}$
}

\author{
${ }^{1}$ Laboratoire d'Océanographie Biologique, Université Pierre et Marie Curie-Paris 6, CNRS, UMR 7621, \\ 66650 Banyuls-sur-Mer, France
}

${ }^{2}$ Adaptation et Diversité en Milieu Marin, Université Pierre et Marie Curie-Paris 6, CNRS-INSU, UMR 7144, Station Biologique de Roscoff, place Georges-Teissier, BP 74, 29682 Roscoff, France

\begin{abstract}
${ }^{3}$ Present address: Laboratoire des Sciences de l'Environnement Marin, UMR 6539 (CNRS-Université de Bretagne OccidentaleIRD), Institut Universitaire Européen de la Mer (IUEM), Place Nicolas Copernic, Technopôle Brest Iroise, 29280 Plouzané, France

${ }^{4}$ Present address: Station Biologique d'Arcachon, UMR 5805, Université Bordeaux 1 - CNRS, 2 rue du Professeur Jolyet, 33120 Arcachon, France
\end{abstract}

\begin{abstract}
We investigated the food web structure of the Salses-Leucate Lagoon (northwestern Mediterranean) through $\delta^{13} \mathrm{C}$ and $\delta^{15} \mathrm{~N}$ analysis of its benthic macrofauna and potential food sources. This lagoon was heavily human-modified during the 1970s, allowing permanent exchange with the open sea and an increase in salinity from that time. As a result, it exhibits a much less marked salinity gradient than the neighbouring lagoon ecosystems, which suggests a priori that its food web structure is more homogeneous. In this environmental context, we assessed spatial variability in the isotopic composition of non-vagrant macrofauna in Salses-Leucate in relation to degree of connection with the open sea, anthropogenic inputs and the presence of oyster aquaculture. Overall, the main trophic pathway is based on suspended particulate organic matter and sedimented organic matter. However, there were marked spatial differences (at different scales) in both $\delta^{13} \mathrm{C}$ and $\delta^{15} \mathrm{~N}$ values of macrofauna, which suggests an important feeding plasticity within each category of primary consumers at a small spatial scale. $\delta^{13} \mathrm{C}$ data showed that the contributions of the different food sources to the diet of primary consumers changed depending on distance from continental inputs, connection with the open sea and local primary producer coverage. Small-scale $\delta^{15} \mathrm{~N}$ variability revealed a very localised influence of anthropogenic nitrogen output. Regarding the possible effect of aquaculture, the isotopic ratios of sediment and macrobenthos were not modified underneath the oyster lines with respect to the neighbouring area. Conversely, the isotopic signature of consumers living on the oyster lines contrasted with those living underneath. Therefore, our results suggest that a decoupling exists between the trophic pathways that occur in the water column and on the soft bottom of this shallow water ecosystem.
\end{abstract}

KEY WORDS: Food web $\cdot$ Lagoon $\cdot \delta^{13} \mathrm{C} \cdot \delta^{15} \mathrm{~N} \cdot$ Spatial heterogeneity $\cdot$ Trophic plasticity Shellfish aquaculture $\cdot$ Northwestern Mediterranean

\section{INTRODUCTION}

Coastal lagoons are among the most productive marine areas (Nixon 1982) and play major ecological roles, such as providing shelter and nursery areas for local and migrant species (Levin et al. 2001). Because they are located at the land-ocean interface, coastal lagoons are especially vulnerable to anthropogenic disturbances associated with tourism, urbanization, industry and agriculture. It is therefore essential to bet- 
ter assess changes in the functioning of these ecosystems in response to natural and/or man-induced changes.

The study of the trophic structure of coastal lagoons is essential in this context. Due to the high diversity of primary producers and other potential food sources, this still remains a challenging task. Stable isotopes have been widely used to identify the main food sources assimilated by consumers and to infer trophic relationships within both terrestrial and marine food webs (Fry 2006). Carbon and nitrogen isotope ratios change in a predictable way when transferred along trophic pathways: the trophic shift between a consumer and its diet is typically low for carbon $(+0.4$ to $+1.3 \%$ ) compared to nitrogen (+2.0 to $+3.4 \%$ ) (Vander Zanden \& Rasmussen 2001, McCutchan et al. 2003, Vanderklift \& Ponsard 2003). Moreover, stable isotopes present relevant advantages compared to conventional gut content analysis techniques: (1) their changes reflect the assimilation rather than the ingestion of food, and (2) they provide time-integrated instead of snapshot assessments of the utilization of different food sources (Tieszen et al. 1983).

Stable isotopes have already proved useful in inferring sound information regarding trophic networks in marine coastal lagoons (Kwak \& Zedler 1997, Machas et al. 2003, Vizzini \& Mazzola 2006). Lagoons occupy more than half of the coastline (40000 ha) of the Languedoc-Roussillon region on the French Mediterranean coast. Although much less investigated than the emblematic Thau Lagoon, which supports an economically important shellfish aquaculture, the more southern lagoons offer great opportunities to study the functioning of lagoon ecosystems. Among them, Lapalme Lagoon is a well-preserved lagoon (Wilke \& Boutière 2000, Ifremer 2006) whose food web has been recently investigated by Carlier et al. (2007a). Carlier et al (2007a) showed that continental inputs may significantly contribute to the food web, and there is a positive gradient in ${ }^{13} \mathrm{C}$-enrichment from the inner to the outer part of the lagoon. The Salses-Leucate Lagoon is located only a few $\mathrm{km}$ south, and differs from Lapalme on 2 main points. First, its exchanges with the open sea have been strongly enhanced by the opening of 3 large artificial connections in the 1970s. As a result, salinity has significantly increased from 12-30 to 27-41 (Wilke 1999) and fauna diversity has been enhanced (Clanzig 1987). Second, it plays an important economical role with activities such as traditional fishing, fish farming and shellfish aquaculture. In particular, a suspended oyster culture area (32 ha) is established in the northern part of the lagoon and produces about $1500 \mathrm{t}$ of oysters per year. Suspended shellfish aquaculture has been shown to affect the functioning of shallow and confined ecosystems such as coastal lagoons (Lamy \& Guerlorget 1995) by enhancing sedimentation (Hatcher et al. 1994) and accelerating nutrient recycling (Mazouni 2004). Recent investigations have shown that fish farming wastes can constitute a food source for cultured bivalves in polyculture systems (Mazzola \& Sara 2001, Yokoyama et al. 2002, Gao et al. 2006), but few studies have dealt with the effect of shellfish aquaculture on the structure of the benthic food web (Dubois et al. 2007).

The main aim of the present study was to assess the structure of the food web in the Salses-Leucate Lagoon based on the analysis of carbon and nitrogen stable isotope ratios of potential food sources and consumers. We were specifically interested in: (1) assessing the magnitude and possible causes of variability in the isotopic compositions of consumers at different spatial scales within the Salses-Leucate Lagoon, and (2) assessing the possible effects of shellfish culture and anthropogenic inputs on the benthic trophic pathways.

\section{MATERIALS AND METHODS}

Study area. The present study was conducted in the Salses-Leucate Lagoon, located in the southwestern part of the French Mediterranean coast (Languedoc Roussillon) (Fig. 1). The climate is characterized by sporadic but heavy rainfall (500 $\mathrm{mm} \mathrm{yr}^{-1}$ ), intense dryness and sunshine. The lagoon is submitted to strong winds ( $\left.>16 \mathrm{~m} \mathrm{~s}^{-1}, 150 \mathrm{~d} \mathrm{yr}^{-1}\right)$ which play a major role in the hydrodynamics of the basin and generate strong resuspension events. The surface of the lagoon is $5400 \mathrm{ha}$, and its maximum water depth is $3.7 \mathrm{~m}$. A shallow sill separates the lagoon into 2 basins. The northern basin is smaller (1540 ha) and shallower (mean depth $=1.5 \mathrm{~m}$ ) than the southern basin (3860 ha, mean depth $=2.1 \mathrm{~m}$ ); this results in 2 distinct water circulation systems with restricted exchanges between the 2 basins.

The catchment area is $160 \mathrm{~km}^{2}$ and continental inputs are limited, especially in the northern basin where temporary streams are dry most of the time (Wilke 1999). The southern basin receives most of the freshwater input via 2 main karstic springs (Font Estramar and Font Dame, $2.3 \mathrm{~m}^{3} \mathrm{~s}^{-1}$ during summer) and from groundwater resurgences, and is then surrounded by extended areas of temporary inundated salt marshes. The lagoon communicates with the Mediterranean Sea by 3 permanent man-made connections (Fig. 1). The salinity is high (mean = 32) and fluctuates both seasonally and spatially between 27 and 41 (Wilke 1999). There is a general positive salinity gradient from the southwestern to the northwestern part of the lagoon (Boutière et al. 1982). Chlorophyll $a$ (chl a) concentration ranges between 2.0 and $4.0 \mathrm{\mu g} \mathrm{l}^{-1}$ 


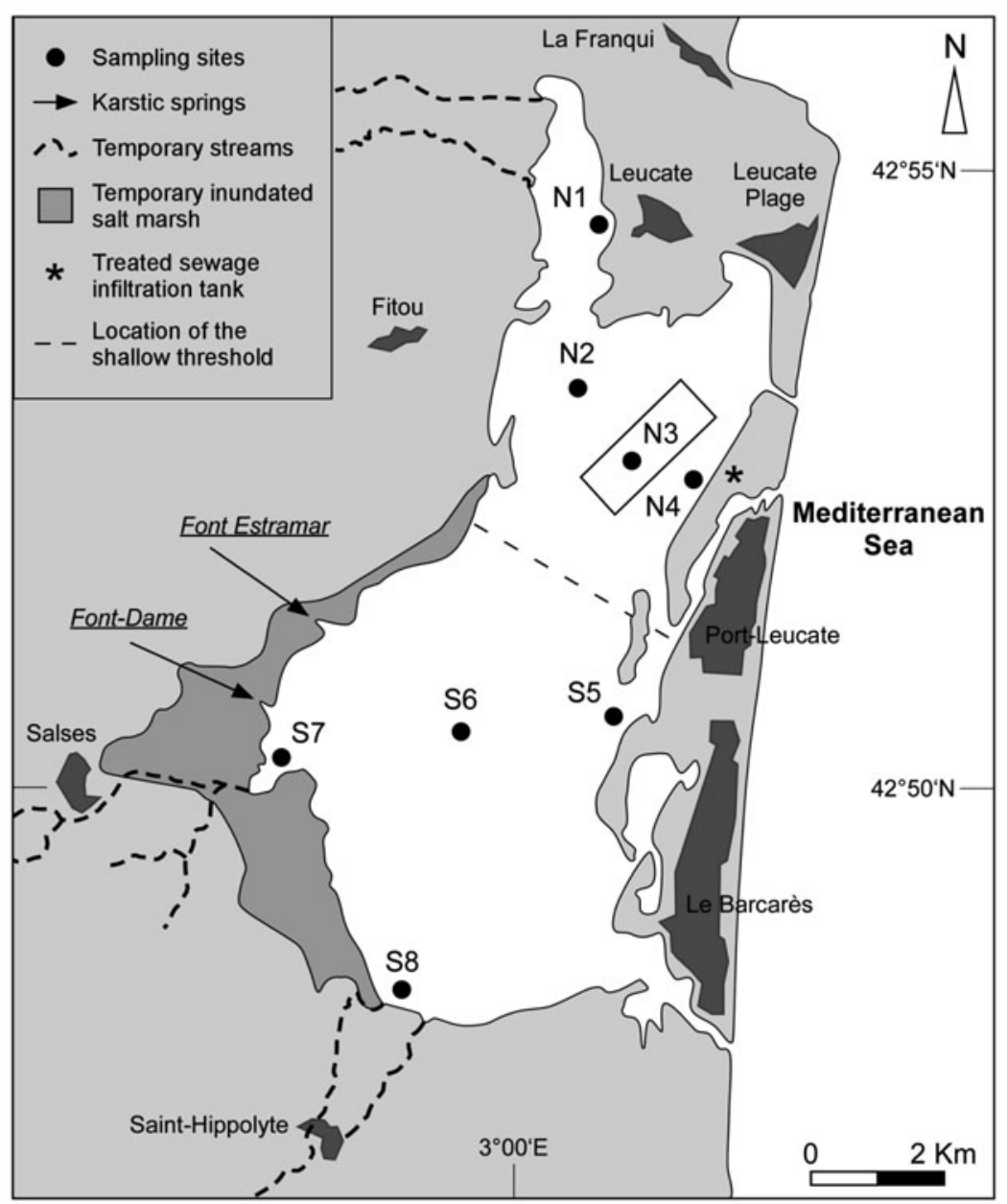

Fig. 1. Salses-Leucate Lagoon showing the location of the sampling sites. The open rectangle within the northern basin corresponds to the oyster culture area. Darker grey shading represents urban areas

and is slightly higher in the southern than in the northern basin (Ifremer 2006). Macrophyte biomass is heterogeneous with values between 0 and $800 \mathrm{~g} \mathrm{DW} \mathrm{m}^{-2}$ (DW = dry weight) (Ifremer 2006). The dominant macrophytes are the seagrass Zostera noltii, Characeae and the macroalgae Chaetomorpha sp., Ulva sp. and Enteromorpha sp. Seven sewage treatment plants (representing an overall capacity of 200000 inhabitants) are located all around the lagoon. The 3 main facilities (Leucate, Port-Leucate and Le Barcarès) are located on the east side of the lagoon. Treated wastewaters from Leucate and Port-Leucate are drained towards sand infiltration beds close to Site N4 (Fig. 1).

Sample collection. Samples were collected between 8 and 20 June 2005 at 8 sites covering the entire Salses-Leucate lagoon (Fig. 1). Five sites were located along the banks of the lagoon (Sites N1, N4, S5, S7 and $\mathrm{S} 8 ;<1 \mathrm{~m}$ depth), 2 sites were located in the center of each basin (Sites N2 and S6; $3 \mathrm{~m}$ depth) and Site N3 was located in the center of the oyster aquaculture area.

Zostera noltii and the dominant macroalgae were hand-collected and carefully scraped to remove epiphytes, which were analyzed separately. Suspended particulate organic matter (POM) was sampled both in the Font Estramar karstic spring and at all 8 sites (Fig. 1). Karstic spring water (8 l) and lagoon water (5 l) were collected about $10 \mathrm{~cm}$ below the surface. Sediment cores were hand-collected at 7 sites and the first $\mathrm{cm}$ was sliced and kept for the analysis of sediment organic matter (SOM). Benthic macrofauna were sampled at all sites. Benthic invertebrates were collected by sieving hand-shovelled sediment on a $1 \mathrm{~mm}$ mesh. Small invertebrates associated with the vegetation (Gammarus aequicauda and Idotea sp.) were collected with a handtowed net $($ mesh size $=1.5 \mathrm{~mm}$ ). At Site N3, macrofauna were sampled both on the oyster-rearing structures (i.e. suspended lines) and on the bottom underneath. Fish were caught with a hand-towed trawl net (mesh size $=1$ $\mathrm{cm})$ at all 5 shallow sites. Overall, 40 species of benthic invertebrates and 14 species of fish were collected. Care was taken to sample animals of similar size from the different locations since significant intraspecific isotopic changes are often linked to body size (Jennings et al. 2002). Isotopic data on salt marsh plants was obtained for the neighbouring Lapalme Lagoon between June 2004 and February 2005 (Carlier et al. 2007a).

Sample processing. Water samples were pre-filtered through a $200 \mu \mathrm{m}$ mesh to remove zooplankton and large detritus. They were then filtered on pre-combusted $\left(500^{\circ} \mathrm{C}, 4 \mathrm{~h}\right.$ ) glass fibre filters (Whatman GF/F) under moderate vacuum (-10 mbar) until clogging. Filters were acidified with $10 \% \mathrm{HCl}$, rinsed with distilled water, dried at $60^{\circ} \mathrm{C}$ and kept frozen at $-20^{\circ} \mathrm{C}$ until being analysed for POM. Epiphytes were resuspended in filtered $(0.45 \mu \mathrm{m})$ lagoon water, collected on GF/F filters and then processed as described above for POM. SOM samples were freeze-dried and ground with a mortar and pestle. A subsample ( 500 mg DW) was acidified with $10 \% \mathrm{HCl}$ and dried at $50^{\circ} \mathrm{C}$ under a fume extractor to evaporate the acid. SOM samples were rinsed with distilled water and dried under the fume extractor to prevent any loss of dissolved organic matter (Riera et al. 1996). This procedure was repeated 
twice. SOM samples were then ground and kept frozen at $-20^{\circ} \mathrm{C}$ until analysis. Invertebrates were starved overnight in filtered $(0.45 \mu \mathrm{m})$ lagoon water and then killed. The flesh of molluscs and crustaceans was then separated from their calcareous shells or external cuticles. Each invertebrate specimen was then analyzed as a whole. Conversely, only the dorsal muscles of fishes were analyzed as their isotopic composition is less variable than that of other body parts (Pinnegar \& Polunin 1999). All animal and plant samples were briefly acidified with $10 \% \mathrm{HCl}$, rinsed with distilled water, dried at $60^{\circ} \mathrm{C}$, ground into fine powder and then kept at $-20^{\circ} \mathrm{C}$ until analysis. Acidification of samples is a key step as it eliminates carbonates, which interfere with $\delta^{13} \mathrm{C}$ measurements; its effect on $\delta^{15} \mathrm{~N}$ values is still unclear. Some authors have reported that acidification significantly affects $\delta^{15} \mathrm{~N}$ values to a degree that may lead to confounding interpretations (Bunn et al. 1995, Pinnegar \& Polunin 1999), whereas others have found only weak (Jacob et al. 2005) or even no significant effect (Bosley \& Wainright 1999). Overall, significant effects of acidification on $\delta^{15} \mathrm{~N}$ values appear to be caused by a prolonged (from 1 to $3 \mathrm{~h}$ ) incubation in acid (Carabel et al. 2006). Our own incubation times were much shorter (typically $<10 \mathrm{~min}$ ), and we are therefore confident in stating that our acidification procedure was appropriate for measuring $\delta^{15} \mathrm{~N}$. Powdered samples were weighed according to sample type (15 mg DW for SOM, $1.0 \mathrm{mg}$ DW for animals, $1.5 \mathrm{mg}$ DW for macrophytes) and put into clean tin cups before stable isotope analysis.

Stable isotope analysis. Isotope analysis was carried out using a Europa Scientific ANCA-NT 20-20 Stable Isotope Analyser with an ANCA-NT Solid/Liquid Preparation Module (Europa Scientific). A 1:4 leucine:citric acid mixture was used as a standard. The isotopic composition $\left(\delta^{13} \mathrm{C}\right.$ or $\left.\delta^{15} \mathrm{~N}\right)$ was expressed as the relative difference between isotopic ratios in the sample and in conventional standards (Vienna Pee Dee Belemnite for carbon and atmospheric $\mathrm{N}_{2}$ for nitrogen):

$$
\begin{gathered}
\delta^{13} \mathrm{C} \text { or } \delta^{15} \mathrm{~N}(\% \circ)= \\
{\left[\left(\mathrm{R}_{\text {sample }} / \mathrm{R}_{\text {standard }}\right)-1\right] \times 1000}
\end{gathered}
$$

where $\mathrm{R}={ }^{13} \mathrm{C} /{ }^{12} \mathrm{C}$ or ${ }^{15} \mathrm{~N} /{ }^{14} \mathrm{~N}$. The precision for $\delta^{13} \mathrm{C}$ was $\sim 0.1 \%$, and for $\delta^{15} \mathrm{~N}$ was $\sim 0.4 \%$ (for samples with $\mathrm{N}$ content $>5 \%$ DW).

Data analysis. In order to assess the level of heterogeneity of the diet of each category of primary consumers (suspension-, interface- and depositfeeders), we compared the variances of $\delta^{13} \mathrm{C}$ values obtained for each feeding guild in the entire lagoon using Bartlett's test, and then we performed pairwise comparisons using F-tests. We used Mann-Whitney $U$-tests to assess between-basin differences in $\delta^{13} \mathrm{C}$ and $\delta^{15} \mathrm{~N}$ values of POM and SOM. We used Wilcoxon signed-rank tests to assess such differences in $\delta^{13} \mathrm{C}$ and $\delta^{15} \mathrm{~N}$ values of consumers. For these tests, we considered the mean $\delta^{13} \mathrm{C}$ and $\delta^{15} \mathrm{~N}$ values of the 19 species of benthic invertebrates that were collected in both basins. We also assessed between-basin differences in $\delta^{13} \mathrm{C}$ and $\delta^{15} \mathrm{~N}$ variability for both suspension- and deposit-feeders by comparing variances using F-tests.

Since interface- and deposit-feeders did not significantly differ by their $\delta^{13} \mathrm{C}$ and $\delta^{15} \mathrm{~N}$ values ( $t$-test, $\mathrm{p}=$ 0.203 and $p=0.658$, respectively), these 2 feeding guilds were later pooled and considered as deposit-feeders in Figs. $4 \& 5$, as well as when between-site differences in $\delta^{13} \mathrm{C}$ and $\delta^{15} \mathrm{~N}$ values of primary consumers were assessed within each basin of the lagoon. In the latter case, non-parametric Kruskal-Wallis tests were used with all $\delta^{13} \mathrm{C}$ values instead of mean $\delta^{13} \mathrm{C}$ values per species, due to the low number of sampled species at some sites.

\section{RESULTS}

\section{Overall food web isotopic characterisation}

The mean $\delta^{13} \mathrm{C}$ and $\delta^{15} \mathrm{~N}$ values of potential food sources are shown in Table 1 and Fig. $2 . \delta^{13} \mathrm{C}$ values of potential food sources ranged from -28 to $-10 \%$. Salt marsh plants and POM from the Font Estramar karstic spring showed the lowest $\delta^{13} \mathrm{C}$ values, whereas the sea-

Table 1. Mean $\delta^{13} \mathrm{C}$ and $\delta^{15} \mathrm{~N}$ values $( \pm \mathrm{SD})$ of potential food sources in both basins of Salses-Leucate Lagoon. POM: suspended particulate organic matter; SOM:

\begin{tabular}{|c|c|c|c|c|c|c|}
\hline \multirow{2}{*}{ Potential food sources } & \multicolumn{3}{|c|}{ Northern basin } & \multicolumn{3}{|c|}{ Southern basin } \\
\hline & $\mathrm{n}$ & $\delta^{15} \mathrm{~N}(\%)$ & $\delta^{13} \mathrm{C}(\%)$ & $\mathrm{n}$ & $\delta^{15} \mathrm{~N}(\% \circ)$ & $\delta^{13} \mathrm{C}(\%)$ \\
\hline \multicolumn{7}{|l|}{ Seagrass } \\
\hline Zostera noltii & 3 & $5.7 \pm 0.5$ & $-9.7 \pm 0.1$ & 3 & $4.7 \pm 0.3$ & $-11.3 \pm 0.1$ \\
\hline Seagrass epiphytes & 1 & 5.8 & -12.0 & 1 & 7.1 & -14.9 \\
\hline \multicolumn{7}{|l|}{ Macroalgae 1} \\
\hline Chaetomorpha sp. & - & - & - & 1 & 7.5 & -17.2 \\
\hline Ulva sp. & 1 & 7.2 & -21.3 & 1 & 7.5 & -21.5 \\
\hline Valonia sp. & 3 & $3.8 \pm 0.5$ & $-17.2 \pm 0.1$ & - & - & - \\
\hline Rhodophyta & - & - & - & 3 & $6.6 \pm 0.5$ & $-20.4 \pm 0.2$ \\
\hline \multicolumn{7}{|l|}{ Macroalgae 2} \\
\hline Acetabularia acetabulum & 1 & 1.0 & -11.4 & - & - & - \\
\hline Characeae & 1 & -0.1 & -11.0 & - & - & - \\
\hline \multicolumn{7}{|l|}{ POM } \\
\hline Lagoon & 4 & $4.7 \pm 1.2$ & $-18.8 \pm 0.9$ & 4 & $5.4 \pm 1.6$ & $-20.5 \pm 0.6$ \\
\hline Karstic spring & - & - & - & 1 & 3.9 & -25.5 \\
\hline SOM & 5 & $4.1 \pm 0.8$ & $-17.8 \pm 2.2$ & 5 & $6.0 \pm 0.8$ & $-19.5 \pm 1.7$ \\
\hline Oyster culture area & 3 & $5.0 \pm 0.2$ & $-17.0 \pm 0.3$ & - & - & - \\
\hline
\end{tabular}
sedimented organic matter 


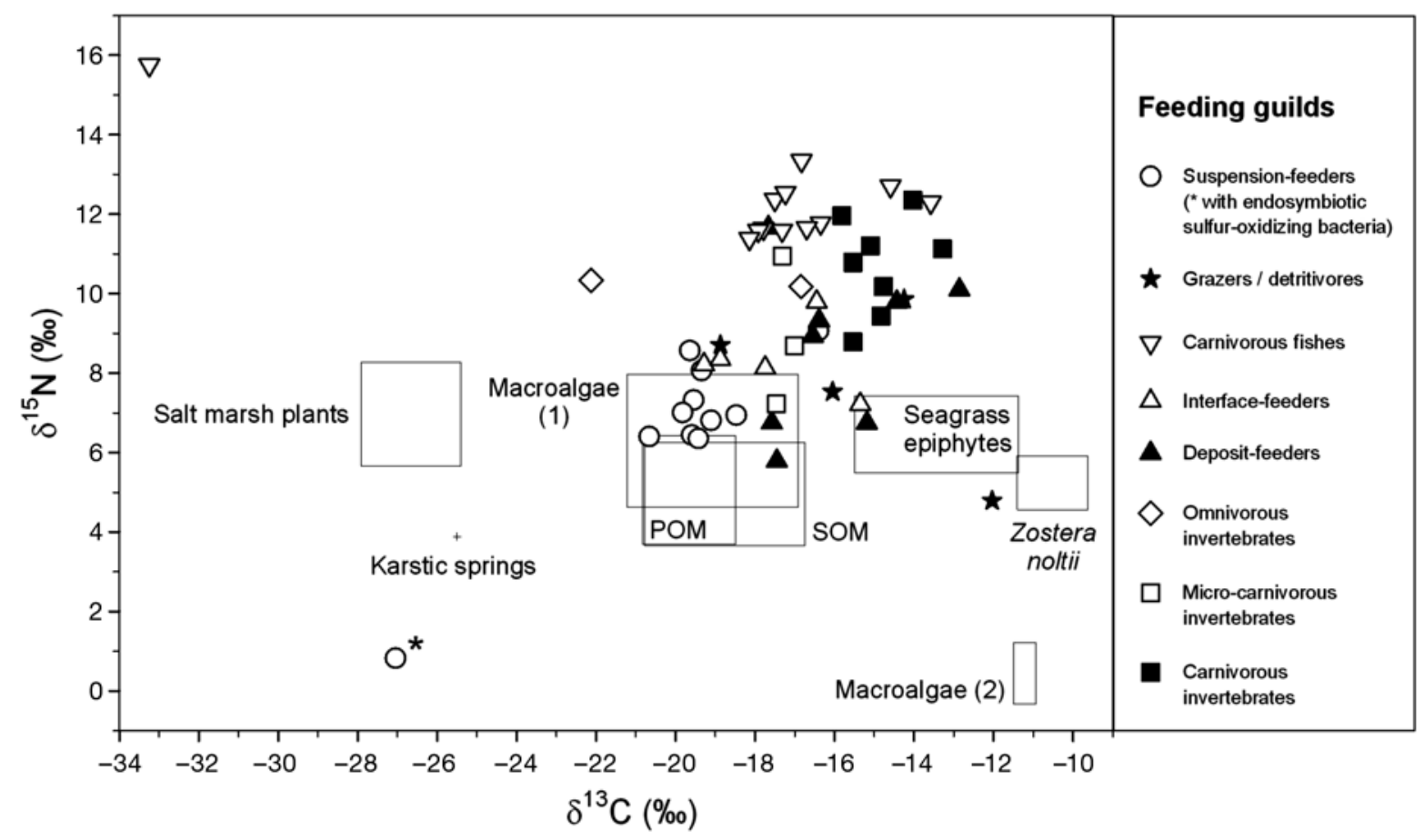

Fig. 2. Dual isotopic plot for all food web components (potential food sources and consumers) in the Salses-Leucate Lagoon. Boxes represent the mean $( \pm \mathrm{SD}) \delta^{13} \mathrm{C}$ and $\delta^{15} \mathrm{~N}$ values of potential food sources. Consumer data are averaged across all replicates and sites. Salt marsh plant data originate from the neighbouring Lapalme Lagoon (Carlier et al. 2007a)

grass Zostera noltii and the macroalgae Acetabularia acetabulum and Characeae (Macroalgae 2) showed the highest $\delta^{13} \mathrm{C}$ values. The macroalgae Chaetomorpha sp., Ulva sp., Valonia sp. and Rhodophyta (Macroalgae 1) and lagoon POM and SOM showed intermediate mean $\delta^{13} \mathrm{C}$ values $(-19.1,-19.7$ and $-18.8 \%$, respectively). $\delta^{15} \mathrm{~N}$ values of potential food sources were more homogeneous than their $\delta^{13} \mathrm{C}$ values. Except for $A$. acetabulum and Characeae, which were clearly more ${ }^{15} \mathrm{~N}$-depleted than all other sources, mean $\delta^{15} \mathrm{~N}$ values ranged between $3.8 \%$ for Valonia sp. and $7.5 \%$ for both Chaetomorpha sp. and Ulva sp.

The mean $\delta^{13} \mathrm{C}$ and $\delta^{15} \mathrm{~N}$ values of consumers averaged over the entire lagoon are shown in Fig. $2 . \delta^{13} \mathrm{C}$ values of the fish Gasterosteus aculeatus (-33.2\%) and the bivalve Loripes lacteus $(-28.0 \%)$, which bears endosymbiotic bacteria, were both clearly lower than those of other consumers. G. aculeatus $\left(\delta^{15} \mathrm{~N}=15.8 \%\right)$ and L. lacteus $\left(\delta^{15} \mathrm{~N}=-0.2 \%\right.$ ) were, respectively, much more ${ }^{15} \mathrm{~N}$-enriched and ${ }^{15} \mathrm{~N}$-depleted than all other consumers. Except for these 2 species, consumers exhibited a continuum of $\delta^{13} \mathrm{C}$ values that ranged from $-22.1 \%$ for the polychaete Perinereis cultrifera to $-12.0 \%$ for the gastropod Haminoea navicula. $\delta^{15} \mathrm{~N}$ values ranged from $4.7 \%$ for the bivalve Nucula hanleyi to $13.3 \%$ for the fish Atherina boyeri. Regarding primary consumers at the lagoon scale, suspensionfeeders showed lower $\delta^{13} \mathrm{C}$ values than interface- and deposit-feeders (Fig. 3). The 3 feeding guilds differed by their $\delta^{13} \mathrm{C}$ variance (Bartlett's test, $\mathrm{p}=0.024$ ). Suspension-feeders exhibited a lower $\delta^{13} \mathrm{C}$ variance than interface- and deposit-feeders ( $F$-test; $\mathrm{p}=0.012$ and 0.015), whereas $\delta^{13} \mathrm{C}$ variances of the 2 latter feeding guilds were not significantly different $(p=0.777)$ (Fig. 3).

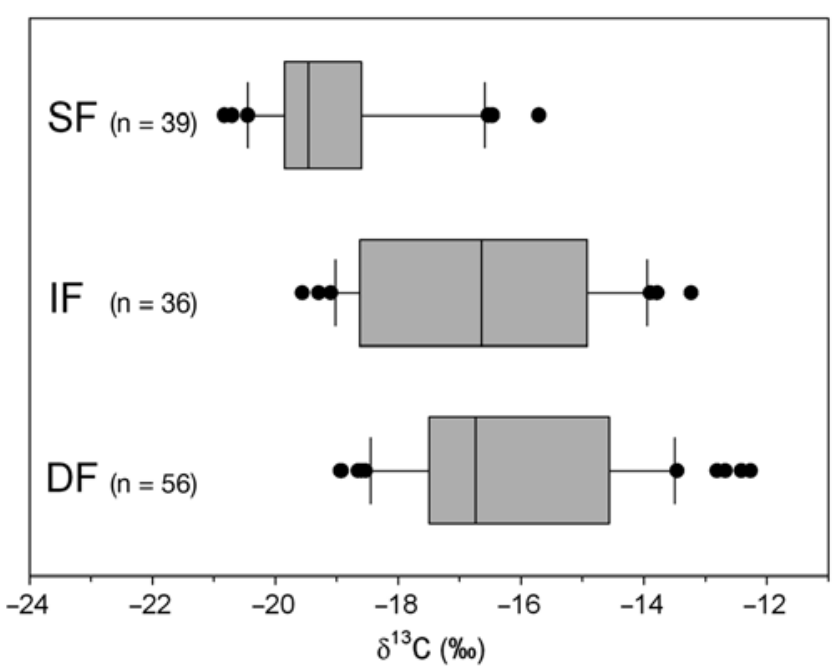

Fig. 3. Scatter plot (showing median, 5th/95th percentiles [whiskers] and outliers [dots]) of all $\delta^{13} \mathrm{C}$ values obtained for suspension-feeders (SF), interface-feeders (IF) and depositfeeders (DF) over the entire Salses-Leucate Lagoon 
Table 2. Mean $\delta^{13} \mathrm{C}$ and $\delta^{15} \mathrm{~N}$ values $( \pm \mathrm{SD}$ ) of consumers collected in both basins of Salses-Leucate Lagoon. Biv: bivalve; Pol: polychaete; Cr: crustacean; Ech: echinoderm; Gas: gastropod; F: fish; Cn: cnidarian. ${ }^{*}$ : bears sulfur-oxidizing endosymbiotic bacteria

\begin{tabular}{|c|c|c|c|c|c|c|}
\hline \multirow{2}{*}{$\begin{array}{l}\text { Feeding guilds } \\
\text { Species }\end{array}$} & \multirow[b]{2}{*}{$\mathrm{n}$} & \multicolumn{2}{|c|}{ — Northern basin } & \multirow[b]{2}{*}{$\mathrm{n}$} & \multirow{2}{*}{ - Southern basin } & \multirow{2}{*}{$\delta^{13} \mathrm{C}(\% \circ)$} \\
\hline & & $\delta^{15} \mathrm{~N}(\%)$ & $\delta^{13} \mathrm{C}(\%)$ & & & \\
\hline \multicolumn{7}{|l|}{ Suspension-feeders } \\
\hline Brachidontes pharaonis (Biv) & 3 & $8.6 \pm 0.2$ & $-19.6 \pm 0.3$ & - & - & - \\
\hline Cerastoderma glaucum (Biv) & 7 & $7.0 \pm 1.0$ & $-17.8 \pm 1.3$ & 4 & $7.1 \pm 0.1$ & $-19.8 \pm 0.8$ \\
\hline Chlamys varia (Biv) & 2 & $6.4 \pm 0.1$ & $-19.6 \pm 0.1$ & - & - & - \\
\hline Crassostrea gigas (Biv) & 3 & $6.4 \pm 0.2$ & $-20.7 \pm 0.2$ & - & - & - \\
\hline Modiolus adriaticus (Biv) & 3 & $7.3 \pm 0.2$ & $-19.5 \pm 0.2$ & - & - & - \\
\hline Mytilus galloprovincialis (Biv) & 3 & $6.3 \pm 0.2$ & $-20.0 \pm 0.1$ & 3 & $7.8 \pm 0.1$ & $-19.7 \pm 0.3$ \\
\hline Paphia aurea (Biv) & 6 & $8.1 \pm 0.4$ & $-19.1 \pm 0.6$ & - & - & - \\
\hline Tapes decussata (Biv) & 3 & $8.7 \pm 1.4$ & $-16.6 \pm 0.8$ & - & - & - \\
\hline Loripes lacteus (Biv*) & 3 & $1.9 \pm 0.5$ & $-26.1 \pm 0.5$ & 3 & $-0.2 \pm 0.9$ & $-28.0 \pm 0.6$ \\
\hline Megalomma vesiculosum (Pol) & 1 & 6.3 & -19.4 & - & - & - \\
\hline Pisidia longicornis $(\mathrm{Cr})$ & 1 & 6.8 & -19.1 & - & - & - \\
\hline \multicolumn{7}{|l|}{ Interface-feeders } \\
\hline Gastrana fragilis (Biv) & 8 & $7.3 \pm 2.3$ & $-14.5 \pm 1.0$ & 4 & $7.1 \pm 0.6$ & $-16.3 \pm 0.3$ \\
\hline Amphitrite rubra (Pol) & 3 & $8.2 \pm 0.1$ & $-19.3 \pm 0.3$ & - & - & - \\
\hline Eupolymnia nebulosa (Pol) & 3 & $8.3 \pm 0.2$ & $-18.9 \pm 0.2$ & - & - & - \\
\hline Thelepus setosus (Pol) & 3 & $11.2 \pm 0.4$ & $-14.2 \pm 0.4$ & 5 & $9.1 \pm 0.3$ & $-17.4 \pm 1.1$ \\
\hline Amphiura chiajei (Ech) & 9 & $7.9 \pm 0.5$ & $-17.6 \pm 1.1$ & 1 & 8.8 & -18.2 \\
\hline \multicolumn{7}{|l|}{ Deposit-feeders } \\
\hline Abra ovata (Biv) & 1 & 5.5 & -15.9 & 4 & $7.0 \pm 0.7$ & $-18.5 \pm 0.1$ \\
\hline Nucula hanleyi (Biv) & 4 & $5.4 \pm 0.6$ & $-17.3 \pm 0.2$ & 3 & $7.0 \pm 0.1$ & $-17.7 \pm 0.4$ \\
\hline Cerithium vulgatum (Gas) & 6 & $9.6 \pm 2.9$ & $-12.9 \pm 0.7$ & 3 & $10.2 \pm 0.2$ & $-17.4 \pm 0.1$ \\
\hline Cirriformia tentaculata (Pol) & 6 & $8.7 \pm 2.0$ & $-14.8 \pm 0.4$ & 9 & $9.1 \pm 0.4$ & $-17.7 \pm 0.8$ \\
\hline Naineris laevigata (Pol) & 3 & $10.9 \pm 0.2$ & $-14.5 \pm 0.1$ & 9 & $8.8 \pm 0.5$ & $-17.0 \pm 0.7$ \\
\hline Notomastus sp. (Pol) & 7 & $7.6 \pm 1.9$ & $-14.8 \pm 1.3$ & 1 & 6.0 & -16.5 \\
\hline Liza aurata $(\mathrm{F})$ & 4 & $10.3 \pm 1.8$ & $-13.1 \pm 1.1$ & - & - & - \\
\hline Mugil cephalus (F) & 1 & 11.7 & -17.7 & - & - & - \\
\hline \multicolumn{7}{|l|}{ Grazers/detritus-feeders } \\
\hline Gibbula albida (Gas) & 4 & $10.7 \pm 2.1$ & $-13.4 \pm 0.4$ & 1 & 10.3 & -15.9 \\
\hline Haminoea navicula (Gas) & 1 & 4.8 & -12.0 & - & - & - \\
\hline Gammarus aequicauda $(\mathrm{Cr})$ & 3 & $8.7 \pm 0.2$ & $-18.9 \pm 0.1$ & - & - & - \\
\hline Idotea sp. $(\mathrm{Cr})$ & 1 & 6.1 & -12.5 & 2 & $8.3 \pm 1.3$ & $-17.8 \pm 1.5$ \\
\hline \multicolumn{7}{|l|}{ Omnivores } \\
\hline Nereis diversicolor (Pol) & 3 & $9.8 \pm 3.0$ & $-16.1 \pm 1.8$ & 1 & 11.2 & -19.2 \\
\hline Perinereis cultrifera (Pol) & 1 & 10.3 & -22.1 & - & - & - \\
\hline \multicolumn{7}{|l|}{ Predators } \\
\hline Nassarius reticulatus (Gas) & 6 & $11.5 \pm 2.0$ & $-13.8 \pm 1.7$ & 6 & $11.6 \pm 0.3$ & $-16.0 \pm 0.6$ \\
\hline Glycera alba (Pol) & 3 & $9.1 \pm 0.7$ & $-13.9 \pm 0.3$ & 3 & $12.4 \pm 0.2$ & $-17.2 \pm 0.9$ \\
\hline Marphysa sanguinea (Pol) & 3 & $8.8 \pm 0.4$ & $-15.5 \pm 0.8$ & - & - & - \\
\hline Nephtys kersivalensis (Pol) & 2 & $8.9 \pm 0.1$ & $-13.9 \pm 0.1$ & 3 & $10.0 \pm 0.3$ & $-15.8 \pm 1.1$ \\
\hline Crangon crangon $(\mathrm{Cr})$ & 2 & $11.1 \pm 1.1$ & $-13.3 \pm 0.5$ & - & - & - \\
\hline Palaemon adspersus $(\mathrm{Cr})$ & 6 & $12.0 \pm 0.2$ & $-15.8 \pm 1.0$ & - & - & - \\
\hline Palaemon serratus $(\mathrm{Cr})$ & 3 & $12.4 \pm 0.4$ & $-14.0 \pm 0.4$ & - & - & - \\
\hline Aiptasia mutabilis (Cn) & 3 & $8.3 \pm 0.1$ & $-16.7 \pm 0.1$ & 3 & $8.8 \pm 0.5$ & $-17.5 \pm 1.0$ \\
\hline Paranemonia cinerea $(\mathrm{Cn})$ & 3 & $10.9 \pm 0.2$ & $-17.3 \pm 0.1$ & - & - & - \\
\hline Rhizostoma pulmo (Cn) & 1 & 7.2 & -17.5 & - & - & - \\
\hline Anguilla anguilla $(\mathrm{F})$ & 4 & $12.0 \pm 0.9$ & $-17.9 \pm 1.7$ & - & - & - \\
\hline Atherina boyeri $(\mathrm{F})$ & 3 & $13.3 \pm 0.7$ & $-16.8 \pm 0.1$ & - & - & - \\
\hline Belone belone $(\mathrm{F})$ & 3 & $11.6 \pm 0.4$ & $-17.8 \pm 0.3$ & - & - & - \\
\hline Cyclope neritea (M) & 6 & $10.8 \pm 1.9$ & $-14.5 \pm 0.7$ & - & - & - \\
\hline Dicentrarchus labrax (F) & 3 & $11.6 \pm 0.2$ & $-17.9 \pm 0.2$ & - & - & - \\
\hline Diplodus sargus $(\mathrm{F})$ & 1 & 11.8 & -16.3 & - & - & - \\
\hline Gasterosteus aculeatus (F) & 3 & $15.8 \pm 0.1$ & $-33.2 \pm 1.1$ & - & - & - \\
\hline Pomatoschistus spp. (F) & 3 & $12.7 \pm 0.5$ & $-14.6 \pm 0.1$ & - & - & - \\
\hline Salaria pavo $(\mathrm{F})$ & 3 & $12.5 \pm 0.7$ & $-17.2 \pm 0.5$ & - & - & - \\
\hline Solea solea $(\mathrm{F})$ & 2 & $12.3 \pm 1.9$ & $-13.6 \pm 0.1$ & - & - & - \\
\hline Sparus aurata $(\mathrm{F})$ & 3 & $11.6 \pm 0.2$ & $-17.3 \pm 0.2$ & - & - & - \\
\hline Syngnathus abaster $(\mathrm{F})$ & 3 & $11.7 \pm 0.6$ & $-16.7 \pm 0.4$ & - & - & - \\
\hline Syngnathus typhle (F) & 3 & $11.4 \pm 0.5$ & $-18.1 \pm 0.5$ & - & - & - \\
\hline
\end{tabular}




\section{Between-basin differences}

Lagoon POM was significantly more ${ }^{13} \mathrm{C}$-depleted in the southern than in the northern basin (Mann-Whitney $U$-test, $p=0.042)$. In the same way, Zostera noltii and seagrass epiphytes showed lower $\delta^{13} \mathrm{C}$ values in the southern than in the northern basin. SOM exhibited slightly lower $\delta^{13} \mathrm{C}$ values in the southern basin, although that difference between basins was not significant $(p=0.377)$. It should be stressed that these $\delta^{13} \mathrm{C}$ values were heterogeneous throughout the lagoon. They ranged from -21.6 to $-16.5 \%$ in the north and from -21.5 to $-18.2 \%$ in the south. $\delta^{13} \mathrm{C}$ values of SOM collected at site N3 (i.e. under the oyster lines) $(-17.0 \pm 0.3 \%)$ was similar to $\delta^{13} \mathrm{C}$ values obtained at the neighbouring site $\mathrm{N} 2(-16.6 \pm 0.1 \%) . \delta^{15} \mathrm{~N}$ values of both POM and SOM did not differ significantly between the 2 basins ( $p=0.470$ and 0.052 , respectively).

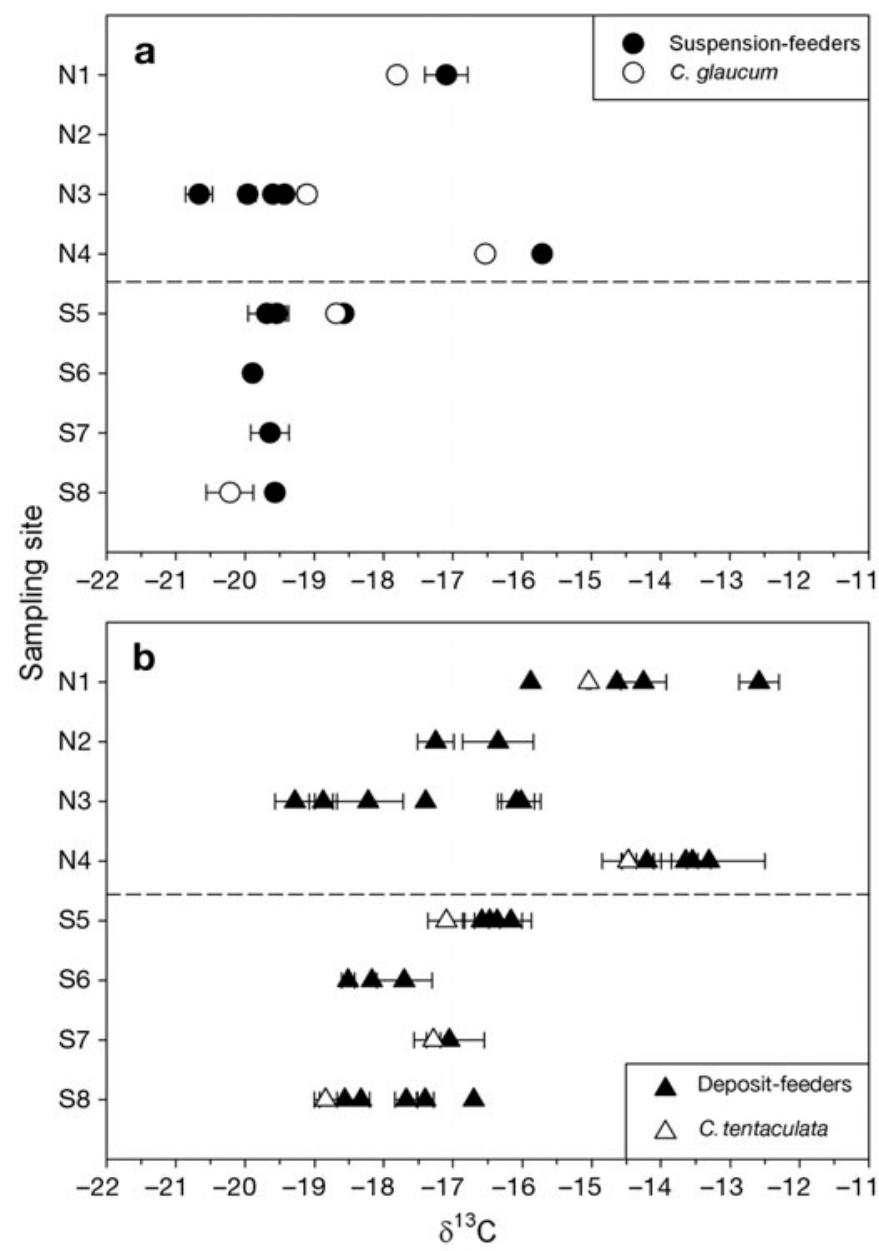

Fig. 4. Spatial variability in $\delta^{13} \mathrm{C}$ of (a) suspension-feeders and (b) pooled interface- and deposit-feeders in Salses-Leucate Lagoon. Each data point represents the mean $\delta^{13} \mathrm{C}$ value $( \pm \mathrm{SD})$ of a single species. Open circles and triangles represent Cerastoderma glaucum and Cirriformia tentaculata, respectively. $(---)$ : sill separating the northern and southern basins

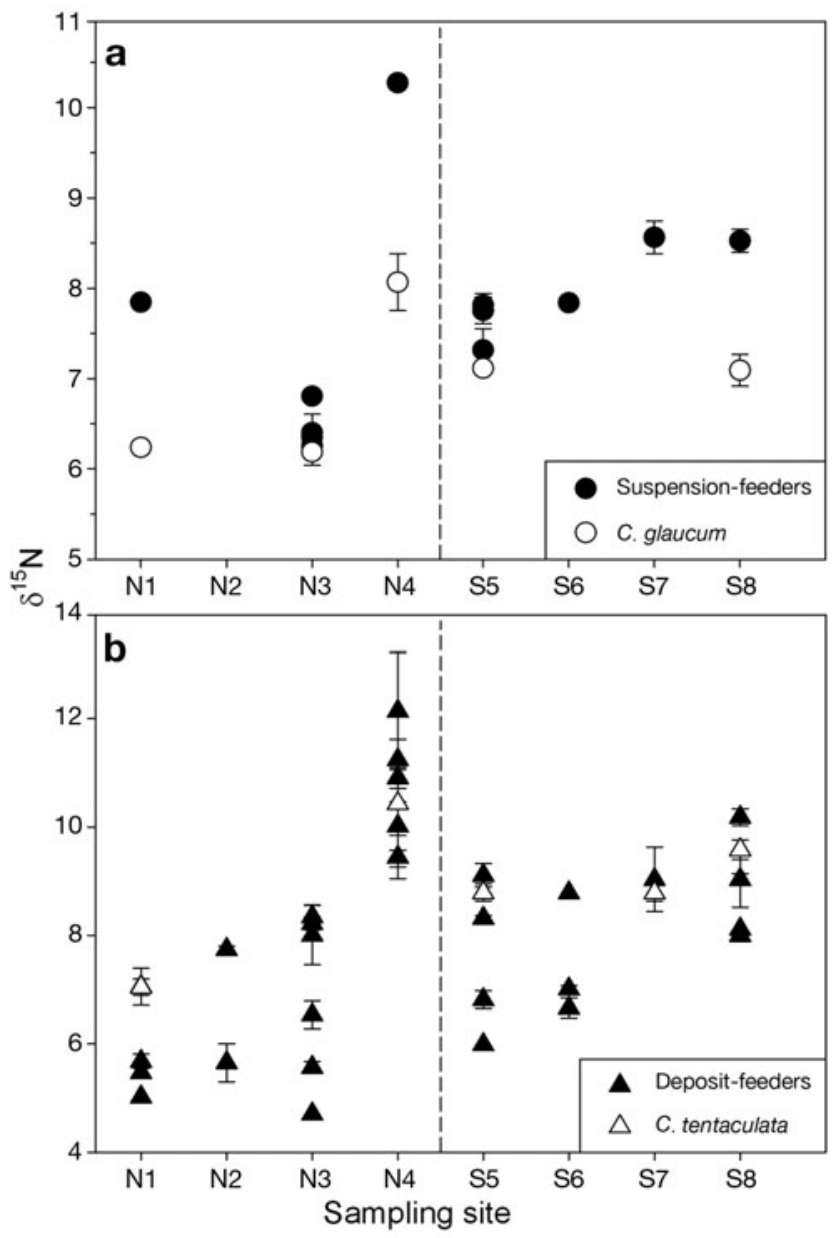

Fig. 5. Spatial variability in $\delta^{15} \mathrm{~N}$ of (a) suspension-feeders and (b) pooled interface- and deposit-feeders in Salses-Leucate Lagoon. Each data point represents the mean $\delta^{15} \mathrm{~N}$ value $( \pm \mathrm{SD})$ of a single species. Open circles and triangles represent Cerastoderma glaucum and Cirriformia tentaculata, respectively. (----): sill separating the northern and southern basins

For each basin of the Salses-Leucate Lagoon, the mean $\delta^{13} \mathrm{C}$ and $\delta^{15} \mathrm{~N}$ values of consumers are shown in Table 2. The 19 species collected in both basins were significantly more ${ }^{13} \mathrm{C}$-depleted in the southern than in the northern basin (Wilcoxon signed-rank test, p < 0.001). Conversely, their $\delta^{15} \mathrm{~N}$ values did not significantly change between basins $(p=0.140)$. The $\delta^{13} \mathrm{C}$ values of suspension-feeders (including Cerastoderma glaucum) and those of interface- and deposit feeders (including Cirriformia tentaculata) were more heterogeneous in the northern basin than in the southern basin ( F-test; $\mathrm{p}<0.001, \mathrm{p}=0.021$ and $\mathrm{p}<0.001$, respectively) (Fig. 4). In the same way, the $\delta^{15} \mathrm{~N}$ values of suspension-feeders and those of interface- and depositfeeders were more heterogeneous in the northern basin than in the southern basin $(\mathrm{p}=0.007$ and $\mathrm{p}<$ 0.001, respectively). 


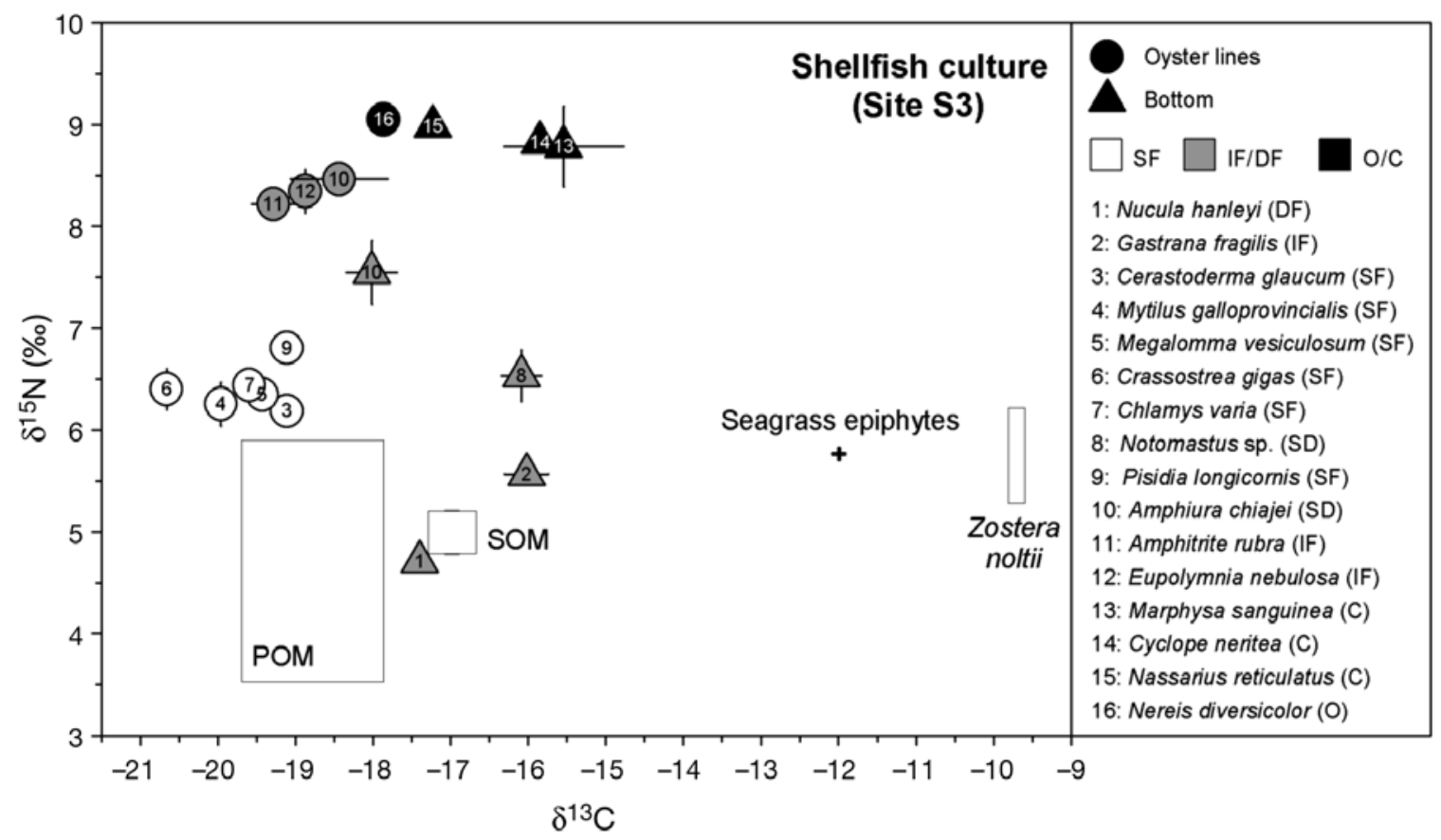

Fig. 6. Dual isotopic plot for consumers sampled within the oyster culture area of the Salses-Leucate Lagoon (Site N3). Boxes represent mean $( \pm \mathrm{SD}) \delta^{13} \mathrm{C}$ and $\delta^{15} \mathrm{~N}$ values for POM (data from northern basin), SOM (Site N3) and Zostera noltii (Site N2). SF: suspension-feeders; IF: interface-feeders; DF: deposit-feeders; O: omnivorous; C: carnivorous

\section{Small-scale spatial variability}

In the southern basin, the $\delta^{13} \mathrm{C}$ values of suspensionfeeders did not significantly differ between sites (Kruskal-Wallis test, $\mathrm{p}=0.075)$. Conversely, $\delta^{13} \mathrm{C}$ of depositfeeders significantly differed between sites $(p<0.001)$, with slightly higher values at Sites S5 and S7 than at Sites $\mathrm{S} 6$ and S8. The $\delta^{15} \mathrm{~N}$ values of suspension-feeders did not significantly differ between sites $(p=0.058)$, whereas $\delta^{15} \mathrm{~N}$ values of deposit-feeders were slightly higher at Sites S7 and S8 than at Sites S5 and S6 ( $\mathrm{p}<0.001)$.

In the northern basin, $\delta^{13} \mathrm{C}$ of suspension- and depositfeeders differed between sites (Kruskal-Wallis test, $\mathrm{p}=$ 0.001 and $p<0.001$ ), with much higher values at Sites N1 and N4 than at Sites N2 and N3. The $\delta^{15} \mathrm{~N}$ of suspension- and deposit-feeders significantly differed between sites as well ( $p=0.008$ and $p<0.001)$, with much higher values at Site N4 than at Sites N1, N2 and N3.

The consumers collected at Site N3 (oyster culture area) showed very distinct $\delta^{13} \mathrm{C}$ and $\delta^{15} \mathrm{~N}$ values depending on sampling location (Fig. 6). Consumers in general, and interface- and deposit-feeders in particular, were significantly more ${ }^{13} \mathrm{C}$-enriched underneath than on the oyster lines (Mann-Whitney $U$-test, $\mathrm{p}<0.001$ and $\mathrm{p}=0.001$, respectively). Interface- and deposit-feeders were significantly more ${ }^{15} \mathrm{~N}$-enriched on than underneath the oyster ropes $(p<0.001)$.

\section{DISCUSSION}

\section{Overall food web structure}

The different categories of potential food sources exhibited a wide range of $\delta^{13} \mathrm{C}$ values. In particular, lagoon POM and SOM showed similar $\delta^{13} \mathrm{C}$ values, both falling in the middle of the $\delta^{13} \mathrm{C}$ range of living primary producers (i.e. salt marsh plants, macroalgae, seagrass and their epiphytes). This $\delta^{13} \mathrm{C}$ pattern was observed in the neighbouring Lapalme Lagoon across all seasons (Carlier et al. 2007a) and is consistent with the well-recognized idea that the SOM pool of estuarine and lagoon ecosystems generally consists of a complex mixture of several sources of organic matter (Nichols \& Allen 1981, Deegan \& Garritt 1997). The range in $\delta^{13} \mathrm{C}$ values found for SOM $(-21.6$ to $-16.6 \%$ o) indicates that the different sources contributed in varying proportions to the SOM pool, depending on the location in the lagoon. For instance, the low $\delta^{13} \mathrm{C}$ value of SOM obtained at Site S7 $(-21.5 \%)$ is likely indicative of the high proportion of organic matter supplied by the abundant and temporarily inundated $\mathrm{C}_{3}$ plant Phragmites communis which grow in the southwestern shore of the lagoon.

Taking into account the small ${ }^{13} \mathrm{C}$-enrichment and the larger ${ }^{15} \mathrm{~N}$-enrichment between a consumer and 
its diet (Vander Zanden \& Rasmussen 2001, McCutchan et al. 2003, Vanderklift \& Ponsard 2003), $\delta^{13} \mathrm{C}$ and $\delta^{15} \mathrm{~N}$ values of consumers suggest that lagoon POM and SOM play a major role in the diet of most benthic organisms in the Salses-Leucate Lagoon (Fig. 2). A similar prevalent trophic role of POM/SOM pools has been shown in the close marine open bay of Banyuls-sur-Mer (Carlier et al. 2007b), as well as in many nearshore ecosystems (Newell 1982). The wide range of $\delta^{13} \mathrm{C}$ values obtained for interface- and deposit-feeders suggests they rely on different components of the SOM pool and in varying proportion (see following sections). Most of the suspension-feeders exhibited tight $\delta^{13} \mathrm{C}$ values around $-20 \%$, consistent with a diet mainly based on marine phytoplankton. Given that POM of coastal ecosystems may be a complex mixture of living and detritic components (Machas et al. 2003), the $\delta^{13} \mathrm{C}$ pattern obtained for suspension-feeders of SalsesLeucate Lagoon may be explained by: (1) a selective assimilation of phytoplankton (Ward \& Shumway 2004), (2) a possible low detritus component in the lagoon POM due to important marine influence, and (3) more homogeneous feeding behaviors (i.e. active filter-feeding) in this category of primary consumers with respect to the deposit-feeders guild.

In addition, results suggest a substantial contribution of other specific sources to several species. The gastropods Cerithium vulgatum, Gibbula albida and Haminoea navicula all exhibited high $\delta^{13} \mathrm{C}$ values $(-14.4,-14.3$ and $-12.0 \%$, respectively) indicative of a large contribution of ${ }^{13} \mathrm{C}$-enriched food sources in their diet. Gibbula sp. and Haminoea sp. are known to feed mainly on diatoms and thin algal film by scraping seagrass leaves (Mazzella \& Russo 1989, Malaquias et al. 2004). In Salses-Leucate, these grazers thus probably used the epiphytes of Zostera noltii, which also featured a high $\delta^{13} \mathrm{C}$ value $(-13.4 \%$ ), thus representing an additional trophic pathway. Moreover, 2 consumers were clearly outliers in the general relationship linking $\delta^{13} \mathrm{C}$ and $\delta^{15} \mathrm{~N}$ and thus departed from the general food web pattern. The low $\delta^{13} \mathrm{C}$ value of the fish Gasterosteus aculeatus $(-33 \%$ ) indicates that it relies mainly on ${ }^{13} \mathrm{C}$-depleted food sources. Although caught in the lagoon, this freshwater species likely feeds in tributaries, where available organic matter originates from freshwater phytoplankton $\left(\delta^{13} \mathrm{C} \sim-30 \%\right.$; Cloern et al. 2002) and terrestrial plants $\left(\delta^{13} \mathrm{C} \sim-28 \%\right.$; Fry \& Sherr 1984). The low $\delta^{13} \mathrm{C}$ value of the bivalve Loripes lacteus $(-27 \%$ ) was due to the fact that a substantial part of its carbon is supplied by endosymbiotic sulfuroxidizing bacteria (Johnson et al. 2002). These bacteria fractionate against ${ }^{13} \mathrm{C}$ during carbon fixation which induces a ${ }^{13} \mathrm{C}$-depletion of bivalve tissues (Spiro et al. 1986).

\section{$\delta^{13} \mathrm{C}$ and $\delta^{15} \mathrm{~N}$ spatial variability of consumers}

\author{
Between-basin differences
}

We investigated spatial changes in the isotopic composition of non-vagrant consumers in order to determine whether or not the general food-web pattern described above was representative of the entire lagoon. Our results showed important isotopic variability at several spatial scales. Spatial heterogeneity in isotopic ratios was first observed between the northern and the southern basins of the Salses-Leucate Lagoon, which are separated by a shallow sill. Overall, POM, seagrasses, SOM and consumers were more ${ }^{13} \mathrm{C}$ depleted in the southern basin, probably reflecting a northward decreasing gradient in continental carbon inputs (including salt marsh plant) that are ${ }^{13} \mathrm{C}$ depleted relative to marine inputs (Fry \& Sherr 1984). Indeed, karstic springs (the dominant freshwater inputs) and salt marshes are both located along the southwestern shore of the lagoon. A similar land-sea $\delta^{13} \mathrm{C}$ trend has been found for primary producers and consumers in Lapalme Lagoon across all seasons (Carlier et al. 2007a), as well as in many other estuarine and lagoon ecosystems (Riera \& Richard 1996, Deegan \& Garritt 1997, Vizzini et al. 2005). The seaward increasing $\delta^{13} \mathrm{C}$ values of aquatic primary producers are most likely due to the fact that the dissolved inorganic carbon fixed during photosynthesis is usually less ${ }^{13} \mathrm{C}$ enriched in freshwater (-10 to $-5 \%$ ) than in seawater $(\sim 0 \%)$ (Fry \& Sherr 1984, Cloern et al. 2002). As a result, the northward increasing $\delta^{13} \mathrm{C}$ values of consumers may: (1) reflect the $\delta^{13} \mathrm{C}$ gradient of submerged primary producers via the assimilation of their detritus, and/or (2) correspond to a greater contribution of continental organic matter to their diet in the inner parts of the lagoon. Concerning the second hypothesis, tributaries probably contribute little to continental carbon inputs since the Salses-Leucate Lagoon (like others in Languedoc-Roussillon) is mostly fuelled by karstic springs with very low POM loads (Kiener \& Petit 1968). Alternatively, ${ }^{13} \mathrm{C}$-depleted $\mathrm{C}_{3}$ salt marsh plants, which grow on the edges of the lagoons and close to freshwater inputs, probably contributed more than karstic springs to the ${ }^{13} \mathrm{C}$-depletion of the food web components in the southern basin. When decaying, they supply important quantities of organic matter (Currin et al. 2003) that may be assimilated via a detritic trophic pathway.

Spatial heterogeneity within the northern basin

We also found spatial changes in the stable isotope ratios of non-vagrant primary consumers within each 
basin of the Salses-Leucate Lagoon. Unexpectedly, consumers of the southern basin, which is larger and receives both terrestrial and seawater inputs, exhibited more homogeneous $\delta^{13} \mathrm{C}$ and $\delta^{15} \mathrm{~N}$ values than their northern counterparts (Figs. $4 \& 5$ ). Therefore, we will only discuss the results obtained in the northern basin, where important isotopic changes were found at small spatial scales (i.e. only a few $\mathrm{km}$ ). In this sense they confirmed previous results regarding other marine coastal ecosystems. For instance, Vizzini \& Mazzola (2006) found that the mean $\delta^{13} \mathrm{C}$ value of polychaetes differed by $\sim 4 \%$ at stations located only $3 \mathrm{~km}$ apart in the Stagnone di Marsala (Western Sicily), and $\delta^{13} \mathrm{C}$ values of the filter-feeder Chione stutchburyi has been shown to vary by $6.8 \%$ over $<4 \mathrm{~km}$ in the AvonHeathcote Estuary, New Zealand (Stephenson \& Lyon 1982). High $\delta^{13} \mathrm{C}$ values measured in Salses-Leucate at Sites N1 and N4 suggest that the contribution of ${ }^{13} \mathrm{C}$ enriched food sources to the diet of primary consumers was higher at these locations than in the rest of the basin. These potential food sources could be seagrass epiphytes, seagrasses, Macroalgae 2 and microphytobenthos. Suspension- and deposit-feeders are not likely to feed on seagrass epiphytes, and the trophic role of seagrasses themselves has been shown to be minor in many coastal ecosystems (Fry 1984, Sullivan \& Moncreiff 1990, Lepoint et al. 2000) but is still debated (Fry 2006). Indeed, when seagrasses are abundant and located in areas with a low hydrodynamism, they can be exploited by consumers via a detritic pathway such as in the Stagnone di Marsala (Vizzini \& Mazzola 2006). Site N1 is located in a confined area of the lagoon, where Zostera noltii meadows are abundant (Ifremer 2005). However, the $\delta^{13} \mathrm{C}$ value of SOM at this site $(-21.6 \%)$ was much lower than in the Stagnone di Marsala (from -15.1 to $-12.6 \%$; Vizzini \& Mazzola 2006), thereby suggesting that seagrass detritus did not contribute significantly to SOM and thus to the diet of benthic primary consumers at Site N1. Conversely, primary consumers collected at Site N1 may have assimilated substantial amounts of macroalgae detritus including the two ${ }^{13} \mathrm{C}$-enriched components Acetabularia acetabulum and Characeae, which both have been reported to colonize the northwestern part of the lagoon (Boutière et al. 1982) and are known to be much more digestible than seagrasses (Carlier et al. 2007a). Finally, microphytobenthos often constitutes an abundant and highly digestible food source in shallow coastal ecosystems (Miller et al. 1996) and may thus account for the high $\delta^{13} \mathrm{C}$ values of primary consumers at Sites N1 and N4. Vizzini \& Mazzola $(2003,2006)$ showed that benthic microalgae of a Mediterranean bay are as ${ }^{13} \mathrm{C}$-enriched ( -15\%) as in intertidal mud flats (Currin et al. 1995). Therefore, interface-feeders such as the tentacle-bearing worm
Cirriformia tentaculata may have assimilated significant amounts of microphytobenthos. Moreover, since resuspension is frequent in the Salses-Leucate Lagoon (Wilke 2001), suspension-feeders may assimilate significant amounts of resuspended benthic microalgae (Miller et al. 1996). Overall, the important between-site differences in the $\delta^{13} \mathrm{C}$ values of primary consumers support the idea that most consumers in marine coastal ecosystems feature a strong trophic plasticity (Jennings et al. 1997, Pinnegar \& Polunin 2000). The capacity of primary consumers to adapt their diet to available food resources could be particularly important in ecosystems such as coastal lagoons, which exhibit a large panel of local and allochthonous sources of organic matter (Vizzini \& Mazzola 2006). Hence the stable isotope approach has been shown suitable to point out food web differences among heterogeneous adjacent habitats within a single coastal lagoon.

In marine coastal ecosystems, $\delta^{15} \mathrm{~N}$ measurement in consumers is an efficient method to detect and trace anthropogenic nitrogen, which is generally much more ${ }^{15} \mathrm{~N}$-enriched than natural nitrogen (McClelland \& Valiela 1998, Riera et al. 2000). High $\delta^{15} \mathrm{~N}$ values were measured for consumers at Site N4. This was probably linked to the presence of treated wastewater effluents, since no high $\delta^{15} \mathrm{~N}$ value was associated with any natural potential food source. Infiltration beds located on the sandy barrier in the immediate vicinity of Site N4 receive outputs from 2 sewage treatment plants (Leucate and Port-Leucate; Ifremer 2006). The ${ }^{15} \mathrm{~N}$ enriched dissolved inorganic nitrogen pool may thus percolate through the sand and mix with the lagoon water. As $\delta^{15} \mathrm{~N}$ was measured in macroinvertebrates whose tissue isotopic compositions have a relatively low turnover rate (typically several weeks or months; Hesslein et al. 1993), this anthropogenically derived nitrogen input seemed not restricted to summer months. However, it does appear to be spatially limited to the area in the immediate vicinity of the infiltration beds, since no ${ }^{15} \mathrm{~N}$-consumer-enrichment was detected at the adjacent sites N1 and N3.

\section{Oyster aquaculture area}

Trophic activity of cultured shellfish is known to enhance the transfer of suspended particles from the water column to the bottom, and to enrich the underlying sediment with organic matter through biodeposition (Hatcher et al. 1994). The oyster culture facilities in Salses-Leucate could thus contribute to the spatial heterogeneity of isotopic values of the macrobenthos in the northern basin. There are few data available about the isotopic shift occurring between bivalves and their biodeposits. Mazzola \& Sara (2001) have 
reported faeces and pseudofaeces of Mytilus galloprovincialis and Tapes sp. to be ${ }^{13} \mathrm{C}$-depleted by 2 to $3 \%$ relative to bivalve tissues. The faeces of many other species have $\delta^{13} \mathrm{C}$ values very similar to those of animal tissues (DeNiro \& Epstein 1978, Codron et al. 2005). As a result, if biodeposits of oysters had a significant impact on the isotopic composition of the underlying fauna, we would have observed a ${ }^{13} \mathrm{C}$-depletion of SOM and benthic consumers at Site N3 compared to the adjacent Site N2. Conversely, $\delta^{13} \mathrm{C}$ of SOM did not differ between Sites N3 and N2, whereas SOM was ${ }^{13} \mathrm{C}$-enriched at Site N3 $(-17.0 \%)$ compared to all other sites. Here again, seagrasses were scarce under the oyster culture area, but benthic microalgae may have contributed substantially to the SOM pool. Large biomasses of microphytobenthos (annual mean value =

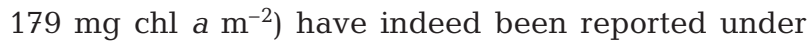
oyster lines in the Thau Lagoon (Barranguet et al. 1994). As noted for SOM, $\delta^{13} \mathrm{C}$ values of the depositfeeder Nucula hanleyi did not differ between Sites N3 and N2. At Site N3, bottom primary consumers (Nucula hanleyi, Gastrana fragilis and Notomastus sp.) relied mainly on SOM as indicated by their $\delta^{13} \mathrm{C}$ values. Suspension-feeders living on the oyster lines had $\delta^{13} \mathrm{C}$ and $\delta^{15} \mathrm{~N}$ values which were similar and $\sim 2 \%$ higher, respectively, than those of POM. Taking into account the isotopic trophic shift between a consumer and its diet, these organisms seem to rely mostly on lagoon POM. Conversely, both interface- and depositfeeders living on the oyster lines showed high $\delta^{15} \mathrm{~N}$ values, which does not support a direct exploitation of lagoon POM. Alternatively, their $\delta^{15} \mathrm{~N}$ values could result from the assimilation of biodeposits produced by oysters and associated suspension-feeders. This hypothesis is consistent with the fact that oyster and mussel lines are known to act as traps for POM and biodeposits (Nizzoli et al. 2005). Further research should compare the $\delta^{13} \mathrm{C}$ and $\delta^{15} \mathrm{~N}$ values of selected suspension-feeders and their biodeposits.

Overall, data obtained at Site N3 suggest no major effect of biodeposition on the isotopic values of the underlying benthic macrofauna. Our results further support the existence of 2 important trophic pathways as already put forward for the entire Salses-Leucate Lagoon: one based on POM and fuelling suspensionfeeders and other consumers on the oyster lines, and another based on SOM fuelling the deposit-feeders underneath. Although benthic-pelagic coupling is known to be a key feature in coastal areas (Graf 1992), data collected at Site N3 thus suggest that this coupling remains weak at least in the central, deeper area of the Salses-Leucate Lagoon.

In conclusion, the present study highlights the need to pay particular attention to small-scale spatial variability before assessing the structure and functioning of land-ocean interface ecosystems by the way of stable isotope analysis. This point is crucial for primary consumers, as they are often (1) considered as a suiteable baseline to estimate the trophic level of omnivorous and carnivorous species and/or (2) used in mixing models for the assessment of relative contribution of potential food sources.

Acknowledgements. This work is in partial fulfillment of the $\mathrm{PhD}$ of A.C. who was supported by a fellowship of the French Ministry of Education Research and Technology. Thanks are due to L. Fonbonne for her information about sewage treatment facilities of the Salses-Leucate Lagoon. This work was partly funded by the EEC Network of Excellence MARBEF through its responsive mode project FOODWEBIO.

\section{LITERATURE CITED}

Barranguet C, Alliot E, Plante-Cuny MR (1994) Benthic microphytic activity at two Mediterranean shellfish cultivation sites with reference to benthic fluxes. Oceanol Acta $17: 211-221$

Bosley KL, Wainright SC (1999) Effects of preservatives and acidification on the stable isotope ratios $\left({ }^{15} \mathrm{~N}:{ }^{14} \mathrm{~N},{ }^{13} \mathrm{C}:{ }^{12} \mathrm{C}\right)$ of two species of marine animals. Can J Fish Aquat Sci $56: 2181-2185$

Boutière $H$, de Bovée $F$, Delille D, Fiala $M$ and others (1982) Effet d'une crise dystrophique dans l'étang de Salses-Leucate. Oceanol Acta 5:231-242

Bunn SE, Loneragan NR, Kempster MA (1995) Effects of acid washing on stable isotope ratios of $\mathrm{C}$ and $\mathrm{N}$ in penaeid shrimp and seagrass: implications for food-web studies using multiple stable isotopes. Limnol Oceanogr 40: $622-625$

Carabel S, Godinez-Dominguez E, Verisimo P, Fernandez L, Freire J (2006) An assessment of sample processing methods for stable isotope analyses of marine food webs. J Exp Mar Biol Ecol 336:254-261

Carlier A, Riera P, Amouroux JM, Bodiou JY and others (2007a) A seasonal survey of the food web in the Lapalme Lagoon (northwestern Mediterranean) assessed by carbon and nitrogen stable isotope analysis. Estuar Coast Shelf Sci 73:299-315

> Carlier A, Riera P, Amouroux JM, Bodiou JY, Grémare A (2007b) Benthic trophic network in the Bay of Banyuls-surMer (northwest Mediterranean, France): an assessment based on stable carbon and nitrogen isotopes analysis. Estuar Coast Shelf Sci 72:1-15

Clanzig S (1987) Inventaire des invertébrés d'une lagune méditerranéenne des côtes de France, biocoenoses et confinement: l'étang de Salses-Leucate (Roussillon). PhD thesis, Ecole Pratique des Hautes Etudes, Paris

Cloern JE, Canuel EA, Harris D (2002) Stable carbon and nitrogen isotope composition of aquatic and terrestrial plants of the San Francisco Bay estuarine system. Limnol Oceanogr 47:713-729

Codron D, Codron J, Sponheimer M, Lee-Thorp JA, Robinson T, Grant CC, DeRuiter D (2005) Assessing diet in savanna herbivores using stable carbon isotope ratios of faeces. Koedoe 48:115-124

Currin CA, Newell SY, Paerl HW (1995) The role of standing dead Spartina alterniflora and benthic microalgae in salt marsh food webs: considerations based on multiple stable isotope analysis. Mar Ecol Prog Ser 121:99-116 
Currin CA, Wainright SC, Able KW, Weinstein MP, Fuller CM (2003) Determination of food web support and trophic position of the mummichog, Fundulus heteroclitus, in New Jersey smooth cordgrass (Spartina alterniflora), common reed (Phragmites australis), and restored salt marshes. Estuaries 26:495-510

$>$ Deegan LA, Garritt RH (1997) Evidence for spatial variability in estuarine food webs. Mar Ecol Prog Ser 147:31-47

$>$ DeNiro MJ, Epstein S (1978) Influence of diet on the distribution of carbon isotopes in animals. Geochim Cosmochim Acta 42:495-506

> Dubois S, Marin-Léal JC, Ropert M, Lefebvre S (2007) Effects of oyster farming on macrofaunal assemblages associated with Lanice conchilega tubeworm populations: a trophic analysis using natural stable isotopes. Aquaculture 271: 336-349

Fry B (1984) ${ }^{13} \mathrm{C} /{ }^{12} \mathrm{C}$ ratios and the trophic importance of algae in Florida Syringodium filiforme seagrass meadows. Mar Biol 79:11-19

Fry B (2006) Stable isotope ecology. Springer, New York

Fry B, Sherr EB (1984) $\delta^{13} \mathrm{C}$ measurements as indicators of carbon flow in marine and freshwater ecosystems. Contrib Mar Sci 27:13-47

Gao QF, Shin PKS, Lin GH, Chen SP, Cheung SG (2006) Stable isotope and fatty acid evidence for uptake of organic waste by green-lipped mussels Perna viridis in a polyculture fish farm system. Mar Ecol Prog Ser 317: 273-283

Graf G (1992) Benthic-pelagic coupling: a benthic view. Oceanogr Mar Biol Annu Rev 30:149-190

- Hatcher A, Grant J, Schofield B (1994) Effects of suspended mussel culture (Mytilus spp.) on sedimentation, benthic respiration and sediment nutrient dynamics in a coastal bay. Mar Ecol Prog Ser 115:219-235

Hesslein RH, Hallard KA, Ramlal P (1993) Replacement of sulfur, carbon, and nitrogen in tissue of growing broad whitefish (Coregonus nasus) in response to a change in diet traced by $\delta^{34} \mathrm{~S}, \delta^{13} \mathrm{C}$, and $\delta^{15} \mathrm{~N}$. Can J Fish Aquat Sci 50: 2071-2076

Ifremer (2005) Réseau de Suivi Lagunaire du LanguedocRoussillon: Bilan des résultats 2004. Report No. RSL-06/ 2005

Ifremer (2006) Réseau de Suivi Lagunaire du LanguedocRoussillon: Bilan des résultats 2005. Report No. RSL-06/ 2006

> Jacob U, Mintenbeck K, Brey T, Knust R, Beyer K (2005) Stable isotope food web studies: a case for standardized sample treatment. Mar Ecol Prog Ser 287:251-253

Jennings S, Reñones O, Morales-Nin B, Polunin NVC, Moranta J, Coll J (1997) Spatial variation in the ${ }^{15} \mathrm{~N}$ and ${ }^{13} \mathrm{C}$ stable isotope composition of plants, invertebrates and fishes on Mediterranean reefs: implications for the study of trophic pathways. Mar Ecol Prog Ser 146:109-116

Jennings S, Pinnegar JK, Polunin NVC, Warr KJ (2002) Linking size-based and trophic analyses of benthic community structure. Mar Ecol Prog Ser 226:77-85

Johnson MA, Fernandez C, Pergent G (2002) The ecological importance of an invertebrate chemoautotrophic symbiosis to phanerogam seagrass beds. Bull Mar Sci 71: 1343-1351

Kiener A, Petit G (1968) Contribution à l'étude écologique de la résurgence de Font-Estramer et de quelques sources vauclusiennes de la région de Salses-La Nouvelle. Vie Milieu 19:241-285

Kwak TJ, Zedler JB (1997) Food web analysis of southern California coastal wetlands using multiple stable isotopes. Oecologia 110:262-277
Lamy N, Guerlorget O (1995) Impact of intensive aquaculture on the soft substratum benthic communities in the Mediterranean lagoonal environments. J Rech Oceanogr 20: $1-8$

> Lepoint G, Nyssen F, Gobert S, Dauby P, Bouquegnea JM (2000) Relative impact of a seagrass bed and its adjacent epilithic algal community in consumer diets. Mar Biol 136:513-518

Levin LA, Boesch DF, Covich A, Dahm C and others (2001) The function of marine critical transition zones and the importance of sediment biodiversity. Ecosystems 4: $430-451$

Machas R, Santos R, Peterson B (2003) Tracing the flow of organic matter from primary producers to filter feeders in Ria Formosa Lagoon, southern Portugal. Estuaries 26: 846-856

Malaquias MAE, Condinho S, Cervera JL, Sprung M (2004) Diet and feeding biology of Haminoea orbygniana (Mollusca: Gastropoda: Cephalaspidea). J Mar Biol Assoc UK 84:767-772

Mazouni N (2004) Influence of suspended oyster cultures on nitrogen regeneration in a coastal lagoon (Thau, France). Mar Ecol Prog Ser 276:103-113

Mazzella L, Russo GF (1989) Grazing effect of two Gibbula species (Mollusca, Archaeogastropoda) on the epiphytic community of Posidonia oceanica leaves. Aquat Bot 35: 357-373

Mazzola A, Sara G (2001) The effect of fish farming organic waste on food availability for bivalve molluscs (Gaeta Gulf, Central Tyrrhenian, MED): stable carbon isotopic analysis. Aquaculture 192:361-379

McClelland JW, Valiela I (1998) Linking nitrogen in estuarine producers to land-derived sources. Limnol Oceanogr 43: 577-585

McCutchan JH Jr, Lewis WM Jr, Kendall C, McGrath CC (2003) Variation in trophic shift for stable isotope ratios of carbon, nitrogen, and sulfur. Oikos 102:378-390

Miller DC, Geider RJ, MacIntyre HL (1996) Microphytobenthos: the ecological role of the 'secret garden' of unvegetated, shallow-water marine habitats. II. Role in sediment stability and shallow-water food webs. Estuaries 19: 202-212

Newell RC (1982) The energetics of detritus utilisation in coastal lagoons and nearshore waters. Oceanol Acta 5:347-355

Nichols M, Allen G (1981) Sedimentary processes in coastal lagoons. UNESCO Tech Pap Mar Sci 33:27-80

Nixon SW (1982) Nutrient dynamics, primary production and fisheries yields of lagoons. Oceanol Acta 5:357-371

Nizzoli D, Welsh DT, Bartoli M, Viaroli P (2005) Impacts of mussel (Mytilus galloprovincialis) farming on oxygen consumption and nutrient recycling in a eutrophic coastal lagoon. Hydrobiologia 550:183-198

> Pinnegar JK, Polunin NVC (1999) Differential fractionation of $\delta^{13} \mathrm{C}$ and $\delta^{15} \mathrm{~N}$ among fish tissues: implications for the study of trophic interactions. Funct Ecol 13:225-231

Pinnegar JK, Polunin NV (2000) Contributions of stableisotope data to elucidating food webs of Mediterranean rocky littoral fishes. Oecologia 122:399-409

- Riera P, Richard P (1996) Isotopic determination of food sources of Crassostrea gigas along a trophic gradient in the estuarine bay of Marennes-Oléron. Estuar Coast Shelf Sci 42:347-360

> Riera P, Richard P, Grémare A, Blanchard G (1996) Food source of intertidal nematodes in the Bay of MarennesOléron (France), as determined by dual stable isotope analysis. Mar Ecol Prog Ser 142:303-309 
Riera P, Stal LJ, Nieuwenhuize J (2000) Heavy $\delta^{15} \mathrm{~N}$ in intertidal benthic algae and invertebrates in the Scheldt Estuary (The Netherlands): effect of river nitrogen inputs. Estuar Coast Shelf Sci 51:365-372

Spiro B, Greenwood PB, Southward AJ, Dando PR (1986) ${ }^{13} \mathrm{C} /{ }^{12} \mathrm{C}$ ratios in marine invertebrates from reducing sediments: confirmation of nutritional importance of chemoautotrophic endosymbiotic bacteria. Mar Ecol Prog Ser 28:233-240

Stephenson RL, Lyon GL (1982) Carbon-13 depletion in an estuarine bivalve: detection of marine and terrestrial food sources. Oecologia 55:110-113

Sullivan MJ, Moncreiff CA (1990) Edaphic algae are an important component of salt marsh food-webs: evidence from multiple stable isotope analyses. Mar Ecol Prog Ser 62:149-159

Tieszen LL, Boutton TW, Tesdahl KG, Slade NA (1983) Fractionation and turnover of stable carbon isotopes in animal tissues: implications for $\delta^{13} \mathrm{C}$ analysis of diet. Oecologia $57: 32-37$

Vander Zanden MJ, Rasmussen JB (2001) Variation in $\delta^{15} \mathrm{~N}$ and $\delta^{13} \mathrm{C}$ trophic fractionation: implications for aquatic food web studies. Limnol Oceanogr 46:2061-2066

Vanderklift MA, Ponsard S (2003) Sources of variation in consumer-diet $\delta^{15} \mathrm{~N}$ enrichment: a meta-analysis. Oecologia 136:169-182

Vizzini S, Mazzola A (2003) Seasonal variations in the stable carbon and nitrogen isotope ratios $\left({ }^{13} \mathrm{C} /{ }^{12} \mathrm{C}\right.$ and $\left.{ }^{15} \mathrm{~N} /{ }^{14} \mathrm{~N}\right)$ of

Editorial responsibility: Hans Heinrich Janssen, Oldendorf/Luhe, Germany primary producers and consumers in a western Mediterranean coastal lagoon. Mar Biol 142:1009-1018

> Vizzini S, Mazzola A (2006) Sources and transfer of organic matter in food webs of a Mediterranean coastal environment: evidence for spatial variability. Estuar Coast Shelf Sci 66:459-467

- Vizzini S, Savona B, Chi TD, Mazzola A (2005) Spatial variability of stable carbon and nitrogen isotope ratios in a Mediterranean coastal lagoon. Hydrobiologia 550: $73-82$

Ward JE, Shumway SE (2004) Separating the grain from the chaff: particle selection in suspension- and deposit-feeding bivalves. J Exp Mar Biol Ecol 300:83-130

Wilke M (1999) Spatio-temporal dynamics of physicochemical and chemical factors in the water of a heavily transformed mediterranean coastal lagoon, the Etang de Salses-Leucate (France). Vie Milieu 49:177-191

Wilke M (2001) Synthèse critique des connaissances sur l'étang de Salses-Leucate et ses conditions abiotiques. Centre d'Etudes Hydrobiologiques, Perpignan

Wilke M, Boutière H (2000) Hydrobiological, physical and chemical characteristics and spatio-temporal dynamics of an oligotrophic Mediterranean lagoon: the Etang de La Palme (France). Vie Milieu 50:101-115

- Yokoyama H, Higano J, Adachi K, Ishihi Y, Yamada Y, Pichitkul P (2002) Evaluation of shrimp polyculture system in Thailand based on stable carbon and nitrogen isotope ratios. Fish Sci 68:745-750

Submitted: December 12, 2007; Accepted: February 27, 2009 Proofs received from author(s): March 28, 2009 